УДК 378.07:005.336.3(438)

DOI:

Катерина Біницька, доктор педагогічних наук, доцент, професор кафедри педагогіки Хмельницької гуманітарно-педагогічної академіі Галина Бучківська, доктор педагогічних наук, професор, професор кафедри образотворчого та декоративно прикладного мистецтва,

Хмельницької гуманітарно-педагогічної академії

Олена Біницька, кандидат економічних наук, доиент, проректор з економічних питань Хмельницької гуманітарно-педагогічної академії

Валентина Греськова, кандидат педагогічних наук, доиент, завідувач кафедри образотворчого та декоративно прикладного мистецтвв Хмельницької гуманітарно-педагогічної академї

\title{
ЄВРОПЕЙСЬКА СИСТЕМА ЗАБЕЗПЕЧЕННЯ ЯКОСТІ ВИЩОЇ ОСВІТИ: ДОСВІД РЕСПУБЛІКИ ПОЛЬЩА
}

Стаття присвячена висвітленню системи забезпечення якості вищої освіти в європейському освітньому npocmopi.

Розглянувши більш детально складні прочеси щуодо внутрішньої системи забезпечення якості вищоі освіти на прикладі краӥни-сусідки Украӥни - члена Свропейського Союзу Республіки Польща -нами з'ясовано, що вона у польських університетах сьогодні не є інновацією. Якість освіти, в польських закладах вищоі освіти оцінюється двома способами. По-перше, використовуючи внутрішні системи забезпечення якості, що є сукупністю нормативно-правових актів, всередині закладах органами влади для закладів вищої освіти. По-друге, залучаючи зовнішні системи, зокрема Польську комісію що є незалежною установою, статутними завданнями якої передбачено проведення оцінок якості освіти в галузях навчання.

Ключові слова: європейський; система; якість освіти; заклади вищої освіти; Республіка Польща. Jim. 10.

Kateryna Binytska, Doctor of Sciences (Pedagogy), Associate Professor; Professor of the Pedagogy Department Khmelnytskiy Humanitarian-Pedagogical Academy

Halyna Buchkivska, Doctor of Sciences (Pedagogy), Professor; Professor of the Decorative-Applied Arts and Labour Training Department, Khmelnytskiy Humanitarian-Pedagogical Academy Olena Binytska, Ph.D. (Economics), Associate Professor, Vice-Rector of Economic Matters, Khmelnytskiy Humanitarian-Pedagogical Academy Valentyna Hreskova, Ph.D. (Pedagogy), Associate Professor of Pedagogical Sciences, Head of the Decorative-Applied Arts and Labour Training Department, Khmelnytskiy Humanitarian-Pedagogical Academy

\section{EUROPEAN QUALITY PROVISION SYSTEM FOR HIGHER EDUCATION: EXPERIENCE OF THE REPUBLIC OF POLAND}

The article deals with the coverage of the quality provision system of higher education in the European educational space. It is emphasized that the idea of creating the systems of quality provision for education appeared in the late $20^{\text {th }}$ century. It is generalized that in 1999 provision of the quality of education was one of the six main goals identified in the framework of the Bologna Process to promote European cooperation in the sphere.

In the process of considering the problem of quality of education and the emergence of the idea of creating its internal provision systems, it was emphasized that the main strategic goal of the process was to create a single European space for higher education. It was found out that this process was initiated with such measures as the approval of unified degrees, introduction of the two-tier system of higher education and credit transfer system ECTS, promotion of students' academic mobility, as well as cooperation in developing and making decisions that ensure high quality of higher education.

The authors state that the quality of educational activity and the quality of educational services in higher education institutions in pedagogical education is treated as training of specialists in accordance with the objective and expected results of the educational process.

Having examined in more details the complex processes concerning the internal quality provision system of higher education on the example of Ukraine's neighbour, a member of the European Union - the Republic of Poland, 


\section{ЄВРОПЕЙСЬКАСИСТЕМА ЗАБЕЗПЕЧЕННЯ ЯКОСТІ ВИЩОЇ ОСВІТИ:}

ДОСВІД РЕСПУБЛІКИПОЛЬЩА

we found out that education quality provision systems in Polish universities are not innovative nowadays. The quality of education in Polish higher education institutions is assessed in two ways. Firstly, using internal quality provision systems, which are a set of regulations of governmental agencies for higher educational institutions. Secondly, the external system is presented by the Polish Accreditation Commission, which is an independent institution that statutory tasks are to assess the quality of education in the field of education. In addition, the Ministry of Science and Higher Education of the Republic of Poland carries out legislative activities and regulates financial instruments that allocate funds to provide universities with high quality education.

Keywords: European; a system; quality of education; institutions of higher education; the Republic of Poland.

П остановка проблеми в загальному вигляді. Ідея створення систем забезпечення якості освіти в європейських країнах з'явилася наприкінці XX ст. та знайшла відображення у дискусіях науковців та керівників урядів освіти, науково-педагогічних працівників, представників органів студентського самоврядування щодо проблем запобігання зниженню рівня освіти. Ця проблема має філософське коріння, згідно з якими джерелом високої якості освітнього процесу є систематичне його внутрішнє оцінювання. Внутрішні системи якості освіти, прагнучи до об'єктивного вимірювання й оцінки якості функціонування закладу вищої освіти та освітньої діяльності, постійно залучають до цього процесу академічну спільноту (адміністрацію закладів) $[3,48-$ 49].

Якість освітньої діяльності та якість надання освітніх послуг у закладах вищої освіти педагогічна спільнота розуміє як підготовку фахівців, відповідно до мети та очікуваних результатів освітнього процесу.

Аналіз досліджень і публікацій. У процесі проведення наукової розвідки з'ясовано, що теоретичні засади дослідження складають положення й висновки польських науковців щодо проблеми запровадження системи забезпечення якості вищої освіти в Республіці Польща та інших європейських країнах, зокрема А. Вроєйнстійна, К. Приступи, М. Тутко, Д. Янковської. Також було проаналізовано нормативно-правову базу, яка регламентує питання системи забезпечення якості вищої освіти в Свропейському Союзі та Республіці Польща.

Формулювання цілей статті. На основі цілісного наукового аналізу обгрунтувати польський досвід запровадження європейської системи забезпечення якості вищої освіти.

Виклад основного матеріалу. Сьогодні в європейській вищій освіті провідною $є$ тенденція до масифікації освітнього процесу та як наслідок цього - зниження якості освіти. Питання якості освіти постало в європейському освітньому просторі внаслідок швидкого кількісного зростання закладів вищої освіти, яке відбулось в середині XX ст. Відповідно до офіційних документів та теоретичних досліджень, прямими причинами виникнення тенденції до масифікації вищої освіти були зміни, що відбувались в Європі, зокрема економічне зростання та соціокультурне піднесення, спричинене науково-технічною революцією розпочатою у XIX ст., а також процесами демократизації, прийняттям ідеології лібералізму та перемогою культури споживання населення. Тому в середині XX ст. з'явилася ідея побудови суспільства, заснованого на знаннях, де вони (а отже, й освіта) є основою соціального й індивідуального розвитку. Науково-технічний прогрес збільшив попит на ринку праці висококваліфікованих працівників, а посилення лібералізму, а також індивідуалістичної та меркантильної раціональності, освіти громадянам, 3 точки зору загальнодоступних цінностей у здійсненні особистих життєвих планів. Тому сьогодні вища освіта розглядається як інструмент, який гарантує економічний та професійний успіх особистості [3, 48-49].

Реформи кінця XX ст. у європейській системі вищої освіти були проведені з метою створення єдиного освітнього простору та залучення закладів вищої освіти до соціально-економічного розвитку об'єднаної Європи. Значення, функції та організаційна форма європейських систем вищої освіти почали визначатися механізмами ринкової економіки, силами наднаціональних та національних, політичних та економічних корпорацій, які реагували на рішення урядів європейських держав.

Беззаперечно, Болонський процес, став головним інструментом змін європейської системи вищої освіти. У контексті розгляду проблеми якості освіти та зародження ідеї створення внутрішніх систем іiі забезпечення варто нагадати, що основною стратегічною метою процесу було створення єдиного європейського простору вищої освіти. Цей процес розпочався із таких заходів, як затвердження єдиних наукових ступенів, запровадження двоступеневої системи вищої освіти та кредитнотранфертної системи ЕCTS, сприяння академічній мобільності студентів, також співпраця у розробці та прийняті рішень, які забезпечують високу якість вищої освіти. Проблема якості вищої освіти почала розглядатись у контексті необхідності їі 
впровадження у систему оцінювання відповідно до прийнятих стандартів та показників [3, 47-50].

Поняття “забезпечення якісної освіти” як загального терміна у вищій школі має багато тлумачень. Так, Європейська асоціація університетів (EUA) у “Грацькій Декларації 2003 року”. зазначає, що “метою європейського виміру забезпечення якості $є$ сприяння взаємній довірі та підвищення прозорості при дотриманні різноманітності національних умов навчання i навчальних процесів" $[2 ; 5,12]$.

Сприяння європейській співпраці в галузі забезпечення якості освіти було однією з шести основних цілей, визначених у рамках реалізації Болонського процесу, розпочатого в 1999 р. Міністри вищої освіти європейських країн визнали вирішальну роль, яку відіграють системи забезпечення якості у дотриманні високих стандартів та сприянні порівнянності кваліфікацій у Свропі.

Одним з головних документів, що стосуються питання якості освіти, є звіт, розроблений Європейською асоціацією вищої освіти, що містить стандарти та вказівки щодо внутрішнього та зовнішнього забезпечення якості вищої освіти. У рамках забезпечення якості внутрішніх систем закладів вищої освіти пропонуються такі дії:

- розробка політики та процедур забезпечення якості (заклади вищої освіти повинні виробити політику та відповідні процедури якості, а також стандарти для програм та їх результатів, які вони пропонують, а також взяти на себе зобов'язання розвивати культуру якості освіти);

- затвердження, моніторинг та періодичний огляд програм і їх наслідків (заклади вищої освіти повинні мати механізми затвердження, періодичного огляду і моніторингу своїх програм та їх ефектів);

- оцінка освітньої діяльності студентів (здобувачів вищої освіти слід оцінювати відповідно до опублікованих та послідовно застосовуваних критеріїв, регламентів і процедур);

- забезпечення якості викладацького складу (заклади повинні гарантувати, що науковопедагогічний колектив має відповідну кваліфікацію та компетенцію);

- навчальні ресурси та заходи підтримки студентів (ресурси, що підтримують навчання студентів, повинні бути достатніми та відповідними для кожної програми);

- інформаційні системи (заклади повинні збирати, аналізувати й використовувати інформацію про ефективне управління запропонованими навчальними програмами та іншими видами діяльності);
- публікація інформації (заклади повинні регулярно публікувати поточну й об'єктивну інформацію у кількісному та якісному відношенні щодо програм, які вони пропонують, та їх ефектів).

Водночас європейські стандарти зовнішнього забезпечення якості вищої освіти повинні проявлятися у таких видах діяльності, як:

- використання внутрішніх процедур забезпечення якості (слід враховувати ефективність внутрішніх процесів забезпечення якості);

- розвиток зовнішніх процесів забезпечення якості (спочатку слід визначити їх цілі та завдання, а потім опублікувати іх разом із описом передбачених процедур);

- критерії прийняття рішень (рішення повинні базуватися на чітко визначених, опублікованих і послідовно застосовуваних критеріях);

- процеси повинні бути придатні для конкретної мети (бути розроблені так, щоб гарантувати їхню придатність для досягнення поставлених цілей $\mathrm{i}$ завдань);

- звітність (публікувати зрозумілі та зручні для користувача звіти);

- періодичність оглядів (періодично слід проводити діяльність у сфері зовнішнього забезпечення якості установ та/або програм i процедур перевірок);

- системний аналіз (слід готувати періодичні підсумкові звіти, що містять обговорення й аналіз загальних висновків оглядів) [5].

Європейський простір вищої освіти характеризується різноманітністю систем вищої освіти та соціокультурними та освітніми традиціями. Цей факт унеможливлює застосування одного підходу до стандартів забезпечення якості освіти у вищій школі конкретної європейської країни. Тому стандарти були побудовані у такий спосіб, щоб застосовувати їх у всіх закладах вищої освіти [9].

Спостерігаючи ситуацію в європейських країнах, не можна сказати, що заклади вищої освіти, з одного боку, та уряди, з іншого, об'єднуються для розв'язання проблеми якості освіти та забезпечення якості. Уряди та заклади вищої освіти можуть мати різні думки щодо таких питань: мета оцінки якості; відповідальність за оцінки (хто що робить?); здатність визначати якість; використання показників ефективності; зв'язок з фінансовими витратами; результати використання зовнішньої системи оцінки якості $[8$, 163].

Розглянемо більш детально складні процеси щодо внутрішньої системи забезпечення якості вищої 
освіти на прикладі країни-сусідки України, члена Свропейського Союзу Республіки Польща [4].

Внутрішні системи забезпечення якості освіти в польських університетах сьогодні не $\epsilon$ інновацією. Їх прихильники заявляють, що головна мета забезпечення та систематичне підвищення якості академічної освіти, реалізується через проведення наукових досліджень та розвиток культури якості завдяки діяльності всіх учасників академічної спільноти.

Протягом останніх двадцяти років у країні на кожному рівні освіти проводяться роботи, спрямовані на реалізацію різних ідей якості освіти - як нової і більш ефективної форми оволодіння знаннями. Нормативно-правовими документами, що регулюють якість управління освітою в Республіці Польща, є: Акт від 27.07.2005 р., Закон “Про вищу освіту”, Положення Міністерства науки та вищої освіти від 5.10.2011 щодо умов проведення досліджень за певною сферою та рівнем освіти, а також розпорядженням № 1 голови Польської акредитаційної комісії від 24.04.2013 р. про систему управління якістю разом 3 додатком [4].

Оцінка якості освіти набула особливого значення в умовах демографічного спаду, спричиненого зменшенням кількості студентів. У 2005/2006 р., закінчився період, який тривав понад десять років, коли відбулося зростання як кількості студентів (1953,8 тис. осіб), так і закладів вищої освіти. Після цього навчального року, протягом багатьох років відзначається тенденція до зниження кількості студентів. У 2016/2017 р., кількість осіб, які здобували вищу освіту, становила лише 1348,8 тис. осіб. Станом на 31 грудня 2018 р. в університетах Республіки Польща навчалися 1230,3 тис. осіб, що на 61,6 тис. менше, ніж у попередньому році [7].

Ця ситуація 3 контингентом студентів поєднується із системою фінансування університету, в якій розмір субсидій суб'єктам господарювання багато в чому залежить від кількості осіб, що навчаються. Намагання отримати більше показників може призвести до прийому на навчання осіб із низькими результатами у середній школі, що потім негативно вплине на адаптацію вимог щодо інтелектуальних здібностей здобувачів вищої освіти. Ці проблеми забезпечення якісної освіти під час навчання відображені в стратегічних документах у галузі вищої освіти Республіки Польща, включаючи Стратегію розвитку вищої освіти до 2020 р. [1].

Якість освіти, в закладах вищої освіти оцінюється двома способами. По-перше, використовуючи внутрішні системи забезпечення якості, що $\epsilon$ сукупністю нормативно-правових актів, в середині закладів встановлених органами влади для закладів вищої освіти. По-друге, зовнішні системи Польська комісія 3 акредитації незалежна установа, статутними завданнями якої $є$ проведення оцінок якість освіти в галузях навчання. Крім того, Міністерство науки та вищої освіти здійснює законодавчу діяльність (наприклад, розробка нормативно-правових актів, імплементація Закону “Про вищу освіту”) та регулює фінансові інструменти, які виділяють університетам кошти для забезпечення високої якості освіти. В результаті у березні 2011 р. було прийнято Закон "Про реформування вищої освіти”, в якому зазначено, що в державний бюджет введено субсидію для суб’ єкта господарювання на співфінансування видатків 3 підвищення якості освіти. Ця субсидія призначається університетам з 2012 р. [5].

Остання зміна правил субсидіювання, пов'язаних з якістю, запроваджена з 2017 р., стосується можливостей фінансування державних університетів для підтримки студентів першокурсників та слухачів магістратури, які отримали найвищі результати навчання.

Однак у Республіці Польща можна визначити негативні тенденції у системі забезпечення якості вищої освіти. Так, про відносно низьку якість освіти свідчать низькі місця польських університетів у міжнародних рейтингах закладів вищої освіти (Шанхайський рейтинг, Рейтинг Лейденського науково-дослідного інституту, Рейтинг університету Ексетера), або ступінь інтернаціоналізації (4,9 \% всіх студентів), один із найнижчих у країнах Свропейського Союзу та OECP (24 місце у 2015 р.). Одна $з$ причин, яка негативно впливає на рівень освіти, сильна дисперсія науки та закладів вищої освіти, що не сприяє використанню потенціалу відповідно до потреб суспільства та громадян, а також державних фінансових ресурсів.

Система забезпечення внутрішньої якості освіти, що функціонує у державних університетах через свою формальну природу недостатньо протидіяла несприятливим явищам, зокрема таким як: відсутність цілісного підходу до перевірки якості освіти та напрямів ії поліпшення; немає визначеного шляху професійного розвитку для викладачів, які беруть участь в освітньому процесі; набір абітурієнтів із низькими шкільними навчальними результатами (від $30 \%$ до $49 \%$ успішності в основному).

За даними Вищої аудиторської служби, у системі вищої освіти занадто мало уваги 


\section{ЄВРОПЕЙСЬКА СИСТЕМА ЗАБЕЗПЕЧЕННЯ ЯКОСТІ ВИЩОЇ ОСВІТИ:}

ДОСВІД РЕСПУБЛІКИПОЛЬЩА

приділяється створенню механізмів, що сприяють якості освіти $[6,7]$.

Запровадження обов'язкової внутрішньої системи забезпечення якості в університетах було введено Постановою Міністерства науки та вищої освіти Республіки Польща від 12 липня 2007 р. “Про стандарти освіти” (переглянута в 2011 р.).

Так, у Законі “Про вищу освіту” зазначено: університети можуть проводити навчання першого чи другого ступеня, якщо вони впровадили систему забезпечення якості освіти, в тому числі заходи щодо вдосконалення програми освіти в галузі навчання [10].

Система якості повинна застосовуватися на всіх етапах й аспектах освітнього процесу, і має враховувати всі форми перевірки результатів навчання окремо, для кожної галузі навчання, а також аналізувати досягнуті студентами навчальні результати, соціальні навички та компетентності, оцінки, отримані здобувачами вищої освіти, висновки з моніторингу професійної кар'єри випускників університету. Заклади вищої освіти зобов'язані контролювати професійну кар'єру своїх випускників для адаптації галузей навчання та програм навчання щодо задоволення потреб ринку праці. Цей процес слід здійснювати через три та п’ять років після закінчення навчання [1].

Перелічені законодавчі вимоги показують, що головна увага приділялась моніторингу якості освіти, і зокрема ступеню адаптації результатів навчання випускників до потреби ринку праці. Моніторинг повинен здійснюватись за системою опитування, що проводиться в основному серед науково-педагогічних працівників університету, студентів та випускників, а також роботодавців. Опитування, очевидно, мають забезпечити високий етичний рівень, поважати добровільність, анонімність та конфіденційність респондентів.

Окремим елементом оцінювання якості освіти $\epsilon$ самооцінка, яку треба здійснювати на різних рівнях структури університету. Результати зібраної інформації мають опубліковуватися та використовуватися для розробки профілактичних та корекційних програм.

Важливо щоб, проведені заходи враховували досягнення мети “досконалості”, яка визначена в Національній рамці кваліфікацій вищої освіти, що чітко відповідає вимогам, задекларованим у Європейському просторі вищої освіти.

Представлені рекомендації враховують принципи побудови та функціонування систем забезпечення якості освіти загалом, виявляють схожість із принципами впровадження системи якості у промисловості 3 принципами забезпечення безпеки, які запроваджені у Польщі в процесі випуску продукції. Ці правила безпеки продукції визначені в Угоді про приєднання Польщі до Свропейського Союзу.

Закон “Про вищу освіту та науку” зобов'язує університети забезпечувати надання якісної освіти, але не визначає умов щодо внутрішнього забезпечення якості, які виходять за рамки загальних принципів навчальних програм i оцінювання викладачів. Детальні рішення регулюються внутрішніми правилами університету. Внутрішнє забезпечення якості включено до зовнішніх оцінок Польської акредитаційної комісії [10].

Зміни та доповнення в нормативно-правові документи, внесені в останнє десятиліття, дали змогу виділити додаткові кошти університетам 3 державного бюджету на діяльність, яка пов’язана iз забезпеченням якості. Інституційні рішення, які передбачають ключову роль Міністра науки та вищої освіти у зовнішньому забезпеченні якості, залишилися незмінними, тоді як сфера зовнішнього забезпечення якості трохи змінилася.

Незважаючи на проведену в 2011 - 2019 рр. модернізацію, все ж у системі освіти залишалися проблеми, серед яких бюрократизація системи освіти (умови створення процедур навчання i акредитації), незадовільна якість освіти та рівень iii адаптації до потреб соціально-економічного середовища, низька ефективність навчання в докторантурі та низький статус академічної кар'єри викладачів у порівнянні 3 науковим шляхом. У відповідь на ці та інші проблеми, які не пов'язані безпосередньо із забезпеченням якості, Міністерство науки та вищої освіти підготувало новий акт про вищу освіту та науку.

Освітня система, яка діє на основі Закону “Про вищу освіту та науку” (2018 р.), все ще включає форми попереднього та позаосвітнього інституційного оцінювання/акредитації для недержавних університетів та попередню оцінку/ акредитаційну програму для всіх університетів. Закон також передбачає впровадження двох нових процесів всебічного оцінювання та оцінювання якості освіти в докторантурі (докторських школах) [10].

Комплексна оцінка буде запроваджена на основі положень Закону, який набере чинності 31 жовтня 2020 р. Він буде зосереджений на ефективності діяльності університету щодо забезпечення якості в усіх сферах, де університет забезпечує освіту. Оцінювання здійснюватиме Польська акредитаційна комісія на вимогу університету. Результатом цього процесу може бути позитивна оцінка на термін надання ліцензії 


\section{ЄВРОПЕЙСЬКА СИСТЕМА ЗАБЕЗПЕЧЕННЯ ЯКОСТІ ВИЩОӤ ОСВІТИ:}

ДОСВІД РЕСПУБЛІКИПОЛЫЩА

від трьох до восьми років або відмова від позитивної оцінки. Протягом періоду позитивного оцінювання, Польська акредитаційна комісія не проводитиме оцінювання програм у освітніх галузях, які віднесені до дисциплін в цих галузях, якщо Міністерство науки та вищої освіти не подасть таку заявку. У разі відмови університет зможе подати заявку на комплексне оцінювання лише через п'ять років [10].

Відповідно до Закону "Про вищу освіту та науку”, у 2018 р. Міністерство науки та вищої освіти надає університетам на конкурсній основі додаткові кошти за трьома програмами, які прямо чи опосередковано пов'язані із забезпеченням якості. У рамках “Дидактичної ініціативи досконалості” державні професійні коледжі отримують кошти на підвищення якості освіти, а умовою їх присудження є оцінки якості РКА за шість років, що передували оголошенню конкурсу та результати моніторингу кар'єри студентів і випускників. Загальна мета програми “Ініціатива передового досвіду: дослідницький коледж” пожвавити міжнародну діяльність закладів. Державні та приватні заклади вищої освіти можуть отримувати кошти для підвищення якості наукової діяльності, в тому числі шляхом активізації міжнародної співпраці та підвищення якості освіти, особливо у пріоритетних наукових напрямах, впровадження рішень у сфері професійного розвитку працівників та вдосконалення управління закладом, включаючи якісні організаційні зміни. Крім того, якщо вони відповідають критеріям якості наукової діяльності, їм виділяють кошти, а також вони повинні керувати докторською школою та не можуть мати негативну оцінку програми, яку перевіряє Польська акредитаційна комісія. Державні та приватні академічні заклади вищої освіти, розташовані в певному регіоні, які $з$ точки зору наукового потенціалу відповідають конкретним науковим критеріям та керують докторською школою, можуть подати заявку на виділення коштів за програмою "Регіональна ініціатива передового досвіду”. Програма спрямована на посилення діяльності закладу освіти 3 конкретних дисциплін, а кошти виділяються на проєкти, що охоплюють стратегію розвитку наукових досліджень, розробок та художньої творчості, відповідно до цілей програми, реалізація яких служить інтенсивному розвитку закладу вищої освіти [10].

Національні нормативні документи не визначають структуру університетів, за винятком того, що ректор визначає критерії, процедуру та оцінювання викладачів за допомогою внутрішньої системи забезпечення якості освіти. Детальні рішення визначені у внутрішніх правилах університету. Університети призначають довірених осіб: ректора, координаторів чи інших осіб, комісії чи інші органи та/або створюють підрозділи, які безпосередньо займаються внутрішнім забезпеченням якості.

Внутрішнє забезпечення якості оцінюється відповідно до “Європейських стандартів та рекомендацій” (ESG). Критерії оцінки Польської акредитаційної комісії враховують усі стандарти ESG, які охоплюють такі аспекти: політика забезпечення якості; розробка та затвердження програми; орієнтоване навчання; навчання та оцінювання; вступ до університету, прогресування, визнання досягнень та кваліфікацій, дипломів; викладацький склад; дидактичні ресурси та підтримка студентів; управління інформацією; публікація інформації; постійний моніторинг та періодичні огляди програм; циклічність зовнішнього забезпечення якості.

Внутрішнє забезпечення якості, як правило, включене в місію системи вищої освіти та науки, яка, відповідно до регламенту, полягає у проведенні моніторингу якості освіти та наукової діяльності, формуванні громадянської позиції, а також участі в соціальному розвитку та створенні економіки, заснованої на інноваціях. Положення не визначають сферу чи елементи внутрішнього забезпечення якості, за винятком загальних принципів забезпечення якості програми та оцінювання викладачів.

Університети повинні систематично оцінювати і вдосконалювати свої освітні програми, які мають враховувати висновки аналізу сумісності результатів навчання $з$ потребами ринку праці й аналізу результатів моніторингу кар'єри студентів та випускників навчання першого і другого магістерського ступеня вищої освіти, проведених Міністром науки та вищої освіти.

Академічна робота усіх науково-педагогічних працівників за винятком ректора університету, підлягає періодичній оцінці. Оцінювання проводиться не рідше одного разу на чотири роки або за поданням ректора. Зокрема, це стосується виконання обов'язків у галузі викладацької та/або наукової діяльності та дотримання прав інтелектуальної власності і приватної власності. Критерії, порядок та організація, за якими проводиться оцінювання, визначаються ректором після консультацій із сенатом, профспілками та органами студентського самоврядування. В оцінці враховуються результати професійної діяльності викладача: виконання ним педагогічних обов'язків, що здійснюються не рідше одного разу на рік. Рейтинг викладача може бути позитивним 
чи негативним. Ректор може припинити трудові відносини $з$ викладачем, який отримав одну негативну оцінку.

Детальні принципи щодо внутрішньої системи забезпечення якості закладені у внутрішніх правилах університетів. Вони включаються до зовнішніх оцінок програм, зроблених Польською акредитаційною комісією.

На національному рівні звіти Польської акредитаційної комісії $є$ основним джерелом сукупної інформації про якість у вищій освіті. Звіти містять статистичні дані про діяльність закладів вищої освіти, а також більш детальний аналіз 3 окремих питань (наприклад, результати програмних оцінок за групами галузей дослідження). В аналітичних розділах Польської акредитаційної комісії висвітлюються сильні та слабкі сторони освітньої і наукової діяльності закладів вищої освіти, а також зміни і тенденції, які впливають на якість його діяльності. Звіти надсилаються в Міністерства, парламент, Раду ректорів та Головну раду з науки та вищої освіти, а також опубліковуються на веб-сайті Польської акредитаційної комісії. Висновки використовуються при прийнятті стратегічних рішень щодо забезпечення якості вищої освіти, а також самою Польською акредитаційною комісією при вдосконаленні освітнього та наукового процесів [1].

Висновки. Вивчивши теоретичні праці зарубіжних науковців на нормативно-правові документи Республіки Польща, можна прийти до висновку, що ця ідея є не новою для європейської та польської вищої освіти.

Узагальнено, що однією із причин запровадження внутрішньої системи забезпечення якості вищої освіти в університетах Республіки Польща були тенденції до масифікації, а також зменшення кількості контингенту студентів що поєднується із системою фінансування закладів вищої освіти, в якій розмір субсидій суб'єктам господарювання багато в чому залежить від кількості студентів, а це може призвести до прийому на навчання осіб із низькими результатами навчання у середній школі, що потім буде мати негативний вплив до адаптації вимог щодо інтелектуальних здібностей здобувачів вищої освіти. Подібна система фінансування існує в Україні, тому вважаємо за доцільне запровадити польський досвід вирішення цієї проблеми, а саме запровадження системи забезпечення якості вищої освіти у вітчизняних закладах вищої освіти.

\section{REFERENCES}

1. Eurydice. Polska. Zapewnienie jakości kształcenia w szkolnictwie wyższym. July, 2020. [Poland Quality Assurance in Higher Education]. Available at: https://eacea.ec.europa.eu/nationalpolicies/eurydice/content/quality-assurance-highereducation-50 pl (Accessed 05 Jun. 2020). [in Polish].

2. Graz Declaration 2003. Forward from Berlin: the Role of the Universities. URL: https://eua.eu/ resources/publications/638:graz-declaration2003.html. (Accessed 15 Jun. 2020). [in English].

3. Jankowska, D. (2013). O wewnętrznych systemach zapewniania jakości w uczelniach polskich w kontekście specyfiki ich genezy i wdrożeń [Internal quality assurance systems at Polish universities in the context of the specificity of their genesis and implementation]. Pedagogika Szkoły Wyższej, 1, ss. 47 62. [in Polish].

4. Przystupa, K. (2017) Jakość kształcenia w uczelni wyższej [The quality of education in higher education institutions]. Available at: file:///C:/Users/ user/Downloads/334 170 A OiZ PRZYSTUPA. pdf https://eacea.ec.europa.eu/national-policies/ eurydice/content/quality-assurance-higher-education50 pl (Accessed 05 Jun. 2020). [in Polish].

5. Standardy i wskazówki dotyczące zapewnienia jakości kształcenia w Europejskim Obszarze Szkolnictwa Wyszego. Europejskie Stowarzyszenie na rzecz Zapewnienia Jakoci w Szkolnictwie Wyższym [Standards and guidelines for quality assurance in the European Higher Education Area. European Association for Quality Assurance in Higher Education], Helsinki Układ graficzny: Pikseri Julkaisupalvelut 2005 r. Available at: https:// d1ihqb7q7sm0xg.cloudfront.net/LSW/web_docs/ $\underline{\text { Standardy }+\mathrm{i}+\text { wskazwki+ dot.+zapewnienia +jakoci }}$ + ksztacenia+w+EOSW.pdf/ (Accessed 05 Jun. 2020). [in Polish].

6. System oceny jakości kształcenia w szkołach wyższych [System of evaluation of the quality of education in universities]. Available at: https:// www.nik.gov.pl/plik/id,18017,vp,20609.pdf(Accessed 05 Jun. 2020). [in Polish].

7. Szkolnictwo wyższe w roku akademickim 2018/ 2019 (wyniki wstępne). [Higher education in the 2018/2019 academic year (preliminary results)]. Available at: https://stat.gov.pl/obszary-tematyczne/ edukacja/edukacja/szkolnictwo-wyzsze-w-rokuakademickim-20182019-wyniki-wstepne, 8,6.html. (Accessed 05 Jun. 2020). [in Polish].

8. Vroeijenstijn, A. I. (1995). Kilka uwag na temat stosowania systemu zewnętrznej oceny jakości w szkolnictwie wyższym: podstawowe zasady i warunki. Systemy oceny jakości szkolnictwa wyższego w wybranych krajach [Some remarks on the application of the external quality assessment system in higher education: basic principles and 


\section{МОДЕЛІПРОФЕСІЙНОЇПДГОТОВКИ СОЦІАЛЬНИХПРАЦІВНИКІВ, ЇХЗМІСТОВО-ТЕХНОЛОГІЧНИЙ СУПРОВІД}

conditions. Higher education quality assessment systems in selected countries]. Jakość szkolnictwa wyższego próby oceny, $\mathrm{Nr}$ 1(5), ss. 158-179. [in Polish].

9. Wewnętrzne systemy zapewniania jakości kształcenia [Internal education quality assurance systems]. Available at: https:// jakosc.uj.edu.pl/-s-wewnetrzne-systemy- zapewniania-jakosci-ksztalcenia (Accessed 05 Jun. 2020). [in Polish]

10. Dz. U. 2018 poz. 1668. Ustawa z dnia 20 lipca 2018 r. Prawo o szkolnictwie wyższym i nauce [Law on higher education and science.]. Opracowano na podstawie t.j. Dz. U. z 2020 r. poz. 85, 374, 695, 875, 1086. [in Polish].

Стаття надійшла до редакції 03.06.2020

УДК 378.147.091.31-051:364.43:005.322

DOI:

Тетяна Опалюк, доктор педагогічних наук, доцент, доцент кафедри сочіальної педагогіки і соціальної роботи, Кам'янеиь-Подільського національного університету імені Івана Огієнка

\section{МОДЕЛІ ПРОФЕСІЙНОЇ ПІДГОТОВКИ СОЦІАЛЬНИХ ПРАЦІВНИКІВ, ЇХ ЗМІСТОВО-ТЕХНОЛОГІЧНИЙ СУПРОВІД}

У статті порушуються проблеми різних підходів, відповідно, різних моделей професійної підготовки соичіальних прачівників, їх змістово-технологічні особливості. Доводиться позиція, щчо професія соиіального працівника, попри спільність фундаментальних теоретико-практичних засад, у різних країнах має різні інтерпретаційні особливості, змістове наповнення, функціональне призначення. Обтрунтовується точка зору, відповідно до якої саме порівняння моделей професійної підготовки соичіальних працівників, у тому числі зарубіжних, дає можливість не лише глибоко проаналізувати вітчизняну систему професійної освіти, а $i$ дослідити потенціал ї̈ розвитку, модернізації відповідно до європейських освітніх стандартів.

Ключові слова: модель професійної підготовки; особистісно орієнтована освіта; компетентнісний підхід; сочіальний працівник; соичіальна робота.

Jim. 5.

Tetyana Opalyuk, Doctor of Sciences (Pedagogy), Associate Professor of the Social Pedagogy and Social Work Department Kamyanets-Podilskiy Ivan Ohiyenko National University

\section{MODELS OF SOCIAL WORKERS PROFESSIONAL TRAINING, THEIR CONTENT AND TECHNOLOGICAL SUPPORT}

The article deals with the problems of different approaches, respectively, of different models of the social workers' professional training. Especially it concerns the content and technological support. It indicates the complexity, the field of functionality, the multidimensionality of the profession, as well as the presence of a large amount of the theoretical and practical research, which determines the possibility of training specialists in this field. The point of view, according to which the comparison of the social worker's professional training models, including foreign ones, provides an opportunity not only to deeply analyze national professional education system, but also to explore the potential of its development in accordance with European educational standards.

The presented analysis of the most typical models of the social workers' professional training shows, that in principle, they can be divided into traditional (providing information and reproductive activities), and innovative (which have a complex structure and determine the relationship between components). Comparison of the most progressive models of social service development, as well as preparation of specialists, indicates the need for their implementation, taking into account: the history of system development; national theoretical and practical developments in this respect; the real possibilities of modern practice. The article presents commonalities of positions that reflect the understanding of social work as: a complex humanistic sphere of activity; professional assistance to individuals, families, groups; an integrative profession that contains elements of professions, designed to help others.

It is also argued, that in different countries the profession of social worker has different interpretative features, meaningful content, functional purpose. A considerable number of factors determine its peculiarities in different countries. However, the comparative analysis not only allows us to trace the mentioned diversity, but also to determine the conditions under which our national professional education system for future social workers can be enriched and improved. This is especially important in the current situation of innovative changes, concerning 